УДК: $355.23(477): 378.5$

Григорій Митрофанович Тіхонов(кандидат військових наук, с.н.с.) $)^{1}$ Сергій Миколайович Шолохов (кандидат технічних наук, доцент) $)^{2}$ Юрій Вікторович Гордієнко ${ }^{2}$

${ }^{1}$ Національний університет оборони Украӥни імені Івана Черняховського, Київ, Украӥна ${ }^{2}$ Національний технічний університет Украйни «Київський політехнічний інститут імені Ігоря Сікорського», Київ, Украӥна

\title{
МЕТОДИКА РОЗРОБКИ СЦЕНАРІЇВ РАДІОЕЛЕКТРОННОГО ТА ЕЛЕКТРОМАГНІТНОГО ПОДАВЛЕННЯ НАЦІОНАЛЬНОЇ ТЕЛЕКОМУНІКАЦІЙНОЇ МЕРЕЖІ В УМОВАХ ОСОБЛИВОГО ПЕРІОДУ
}

Завадозахист системи зв'язку є актуальним та важливим напрямом дослідження, методологія оијнки впливу на нього засобів радіо (РП) та електромагнітного подавлення (ЕМП), на сьогоднішній день, досить розвинута та відома. Національна телекомунікаційної мережа (НТМ), як сукупність систем і мереж зв'язку, в умовах ведення гібридної війни проти Украӥни потребує вдосконалення способів ї̈ захисту від деструктивного впливу противника, щуо має на озброєнні новітні засоби РП та ЕМП. Незахищена НТМ не зможе виконати основну свою функиію, а саме обіг (передавання, приймання, створення, оброблення, зберігання) та захист національних інформаційних ресурсів, забезпечення захищених електронних комунікацій, надання спектра сучасних захищених інформаційно-комунікаційних (мультисервісних) послуг в інтересах здійснення управління державою у мирний час, в умовах надзвичайного стану та в особливий період, яка є мережею (системою) подвійного призначення 3 використанням частини ї ресурсу для надання послуг спеціального зв'язку, зокрема з кіберзахисту, іншим споживачам. Якісна розробка способів та методів забезпечення завадостійкості елементів НТМ неможлива без прогнозування можливих сценарїв дій противника та завадової обстановки, що може скластися.

Запропоновано застосування сиенарного підходу під час розробки адаптивних алгоритмів завадозахисту засобів спечіального зв'язку від активного радіо та електромагнітного подавлення противника в гібридних діях та терористичній діяльності.

Розроблено методику обтрунтування сценаріїв РП та ЕМП транспортної платформи (ТП) НТМ та визначення сценаріїв складної сигнально-завадової обстановки. Дані сценарії необхідні для подальшого синтезу адаптивних алгоритмів завадозахисту засобів транспортної платформи НТМ.

Методика дозволяє обтрунтувати склад та порядок застосування засобів РП та ЕМП противника у часі та по елементах транспортної платформи НТМ в умовах ведення гібридної війни проти Украӥни.

Зроблено висновок щзодо необхідності синтезу алгоритмів завадозахисту каналів зв'язку адаптивних до різних сиенаріїв сигнально-завадової обстановки, щзо може скластися.

Ключові слова: електромагнітнеподавлення; радіоелектроннеподавлення; сиенарії радіоподавлення; завадозахист.

\section{Ветуп}

Теперішній момент часу характеризується можливістю різкого загострення ситуації на Сході та Півдні України, переходом російськотерористичних військ до широкомасштабної збройної агресії проти України або веденням масштабних терористичних дій в умовах особливого періоду.

В таких умовах першочерговими об'єктами (Об) радіоподавлення (РП) та електромагнітного подавлення (ЕМП) противника [1] можуть стати як елементи радіосегмента транспортної платформи НТМ, що розташовані в зоні проведення операції об'єднаних сил (ООС), так і ті, що знаходяться на решті території України.

Постановка проблеми. Для системи зв'язку в умовах можливого створення противником складної сигнально-завадової обстановки (СС3О), якісне виконання завдань за призначенням вимагає розробки та застосування у приймачах адаптивних до сценаріїв ССЗО алгоритмів завадозахисту. Це потребує автоматизованого розпізнавання станів

(C) Г.М.Тіхонов, С.М.Шолохов, Ю.В.Гордієнко

Modern Information Technologies in the Sphere of Security and Defence № 3(39)/2020 ISSN2311-7249(Print)/ISSN2410-7336(Online) 
ССЗО за апріорним словником нечітких сигнатур для подальшої обробки корисного сигналу.

Вирішення цього завдання можливо із розвитком галузі радіоелектронної боротьби (РЕБ) та теорії завадозахисту сценарного підходу [2, 3]. Одним із завдань, що виникає при цьому, $\epsilon$ розробка методики визначення сценаріїв РП та ЕМП (застосування новітніх засобів та способів РП та ЕМП) Російською Федерацією транспортної платформи НТМ в потенційних, реальних бойових діях та у гібриднійвійні на території України.

Розуміння «сценарій РП та ЕМП» не досліджене та нове для теорії радіоелектронної боротьби та завадозахищеності.

Існує безліч різних визначень понять «сценарій». Одне 3 них трактує сценарій як послідовність прогнозованих подій у часі $[2,3]$.

Загальними характеристиками сценаріїв $\epsilon$ : гіпотетична природа сценарію; опис альтернативних варіантів майбутнього; опис майбутнього як кінцевого результату або ж як ланцюжка подій; причинно-наслідковий зв'язок і наявність внутрішньої узгодженості; можливість використовувати сценарій як базис для дій; описова природа; достовірність; пояснювальна природа; з'єднання минулого, сьогодення і майбутнього [3, 4].

В результаті узагальнення цих характеристик введемо в якості найбільш загального визначення сценарію радіо- та електромагнітного подавлення транспортної платформи НТМ наступне: сценарій РП та ЕМП транспортної платформи НТМ - це послідовний опис альтернативних гіпотетично можливих варіантів застосування засобів РП та ЕМП в майбутніх гібридних діях, який відображає різні можливі тактичні та оперативно-тактичні ситуації їх застосування, а також який може бути вихідними даними для розробки методів та способів протидії зриву інформаційного обміну у транспортній платформі НТМ в умовах РП та ЕМП противника. Визначення сценаріїв РП та ЕМП систем зв'язку $є$ завданням проведення сценарного дослідження. Кожне таке дослідження має свою специфіку і відрізняється від інших.

Аналіз останніх досліджень і публікацій.

Питання оптимізації розподілу засобів РП за об'єктами впливу розглянуті в [5-7]. Однак, у відомій літературі можливі сценарії та способи радіо та електромагнітного подавлення транспортної платформи НТМ мало досліджені. Постановки задачі раціонального розподілу ресурсу неоднорідних засобів радіоелектронної боротьби противника за елементами транспортної платформи НТМ для подальшої розробки методики визначення сценаріїв іiі РП в умовах ведення гібридних бойових та терористичних дій проведена в [6]. Методика оцінки показників якості порушення інформаційного обміну в транспортній платформі НТМ в умовах ведення РП розроблена в [7]. У проаналізованій авторами літературі, методика визначення сценаріїв РП та ЕМП радіоканалів зв'язку транспортної платформи НТМ для синтезу адаптивних алгоритмів їх завадозахисту 3 урахуванням можливих сценаріїв складної сигнально-завадової обстановки не досліджена у повному обсязі.

Метою статті $є$ розробка методики визначення сценаріїв РП та ЕМП транспортної платформи НТМ та складної сигнально-завадової обстановки для синтезу адаптивних алгоритмів завадозахисту в умовах ведення гібридних та терористичних дій на території України.

\section{Виклад основного матеріалу дослідження}

Мета статті буде досягнута на основі розвитку математичного апарату теорій вирішення багатоіндексних задач оптимального розподілу різнорідного ресурсу $[8,9]$, математичної статистики [10] та ідентифікації систем [11] в практичну площину застосування сценарного підходу для визначення сценаріїв РП та ЕМП транспортної платформи НТМ та ССЗО під час ведення гібридних війн та терористичних дій.

Проведені дослідження показали, що у загальному вигляді методика містить п'ять етапів, рис.1:

I - формування множини вхідних даних;

II - визначення множини гіпотетично можливих засобів деструктивного впливу противника на елементи транспортної платформи НТМ у гібридних діях;

III - оптимізацію розподілу ресурсу різнорідних засобів РП та ЕМП противника, що можуть бути застосовані для визначення сценаріїв РП та ЕМП противника на транспортній платформі НТМ;

IV - визначення послідовності застосування засобів РП та ЕМП противника у часі та просторі при виконанні підрозділами Держспецзв'язку завдань за призначенням в умовах РЕБ противника при веденні гібридних дій та терористичної діяльності;

V - визначення можливих сценаріїв С3О та масивів їх сигнатур та ознак під час застосування підрозділів Держспецзв'язку в умовах РП та ЕМП противника, прогнозування ії змін у часі. Розробка математичних моделей сценаріїв складної СЗО для формування апріорних масивів сигнатур та ознак для розпізнавання сценаріїв.

Перший етап методики труднощів не викликає. На цьому етапі проводиться формування множини вхідних даних шляхом аналізу гіпотетично можливих засобів РП, ЕМП противника та загальної радіоелектронної обстановки (РЕО). При цьому в доповнення до загальноприйнятих та визначених заходів необхідно: 
проаналізувати порядок комплексного застосування засобів радіозв'язку транспортної платформи НТМ (типи супутникових засобів передачі інформації, радіорелейних та УКХ засобів зв'язку, частотно-часові параметри їх сигналів та швидкості передачі даних у лініях, утворених ними, взаємозамінність, види модуляції (маніпуляції) тощо;

проаналізувати можливості частин (підрозділів) радіоелектронної розвідки та РЕБ російсько-терористичних військ;

окремої оцінки вимагають можливості засобів ЕМП противника та їх засоби доставки до об'єктів ураження під час гібридних дій та терористичної діяльності на території України.

На основі результатів оцінки радіоелектронної обстановки формується множина вихідних даних для визначення сценаріїв деструктивного радіоелектронного впливу на елементи транспортної платформи НТМ.

На другому етапі методики обгрунтовуються гіпотетично придатні для виконання завдань з РП, ЕМП засоби деструктивного впливу, що $є$ (або можуть бути в перспективі) на озброєнні російсько-терористичних військ.

На третьому етапі методики проводиться оптимізація розподілу ресурсу існуючих та гіпотетично можливих засобів РП та ЕМП противника за об'єктами впливу транспортної мережі НТМ для формування основи визначення сценаріїв деструктивного впливу.

На четвертому етапі методики визначаються просторові, часові показники та порядок застосування засобів РП та ЕМП по елементах транспортної мережі НТМ. Це потребує детального врахування завдань, тактичних та оперативно-тактичних показників ведення гібридних дій та терористичної діяльності

У розробленій методиці наукового вдосконалення набули:

постановка зворотної задачі векторної оптимізації розподілу ресурсу неоднорідних засобів РП та ЕМП за елементами транспортної мережі НTM [6];

пониження мірності векторної задачі оптимізації та перетворення іiі до виду однокритеріальної задачі розподілу різнорідних засобів РП та ЕМП по елементах транспортної мережі НТМ;

порядок

вирішення

зворотної однокритеріальної задачі раціонального розподілу різнорідних засобів РП з врахуванням обмежень на ефективність зриву інформаційного обміну у транспортній мережі НТМ [6];

порядок оцінки ефективності порушення інформаційного обміну у транспортній мережі НТМ та обгрунтування обмежень до неї [7].

$\mathrm{He}$ гублячи загальності викладення, конкретизуємо порядок практичного застосування отриманих результатів при визначенні сценаріїв РП та ЕМП транспортної мережі НТМ.

Нехай, за результатами аналізу (РЕО) визначено що противник для вирішення завдань 3 РП та ЕМП транспортної мережі НТМ може гіпотетично застосувати засоби РП та ЕМП $\mathrm{k}$ типів, $\mathrm{k}=1,2, \ldots, \mathrm{v}$.

Противник під час підготовки та ведення гібридних дій (терористичної діяльності) ставить завдання зірвати обмін інформацією каналами державного управління у певному територіальному районі України, що залежить від масштабів гібридних дій. При цьому, в залежності від масштабів гібридних дій, противник вирішує j часткових завдань $\mathrm{Z}_{1}, \mathrm{Z}_{2}, \ldots, \mathrm{Z}_{\mathrm{m}}, \mathrm{j}=1,2, \ldots, \mathrm{m}$, рис.2. Зокрема, під час ведення гібридних бойових дій завданнями можуть полягати в наступному:

Наприклад, здійснення за єдиним замислом та планом РП та ЕМП засобів транспортної мережі НТМ в наступних просторових масштабах (рис.2):

( $\mathrm{j}=1$ ) - до 100 км від лінії розмежування;

( $\mathrm{j}=2$ ) - до 250 км від лінії розмежування;

( $\mathrm{j}=3$ ) - до 500 км від лінії розмежування;

( $\mathrm{j}=4)$ - на всю глибину території України.

При цьому вважається, що завдання 3 подавлення інших видів зв'язку в інтересах державного управління повністю виконані окремими діями.

В рамках вирішення кожного $\mathrm{j}$-го завдання за результатами попередньої РP противником викрито $n_{j}$ типів функціонально незалежних елементів транспортної мережі НТМ - об'єктів (Об) РП та ЕМП. Q $\mathrm{z}$-го типу (терміналів ТП), $\mathrm{z}=1,2, \ldots, \mathrm{n}_{\mathrm{j}}$, рис. 2. Кожен об’єкт організовує одну радіолінію ТП, яка за ТTX терміналу $\epsilon$ багатоканальною i, в залежності від ланки управління, включає в себе від одиниць до десятків радіоканалів.

На рис. 2 умовно схематично показані радіолінії транспортної мережі НТМ, які організовані об'єктами РП та ЕМП на глибину завдання $Z_{j}, j=1,2,3$ та 4 відповідно.

За результатами оцінки РЕО визначена загальна кількість радіоканалів $Q_{j}$, яка організована на всіх об'єктах z типів, що можуть бути об'єктами РП та ЕМП противника під час виконання j-го завдання. $\mathrm{Q}_{\mathrm{j}}=\sum_{\mathrm{z}=1}^{\mathrm{n}_{\mathrm{j}}} \mathrm{Q}_{\mathrm{jz}} \cdot \mathrm{A}_{\mathrm{jz}}$, де $\mathrm{A}_{\mathrm{jz}}$ - кількість радіоканалів, організованих однією радіолінією об'єкта z -го типу під час виконання противником $\mathrm{j}$-го завдання. 


\section{Військова кібернетика та системний аналіз}

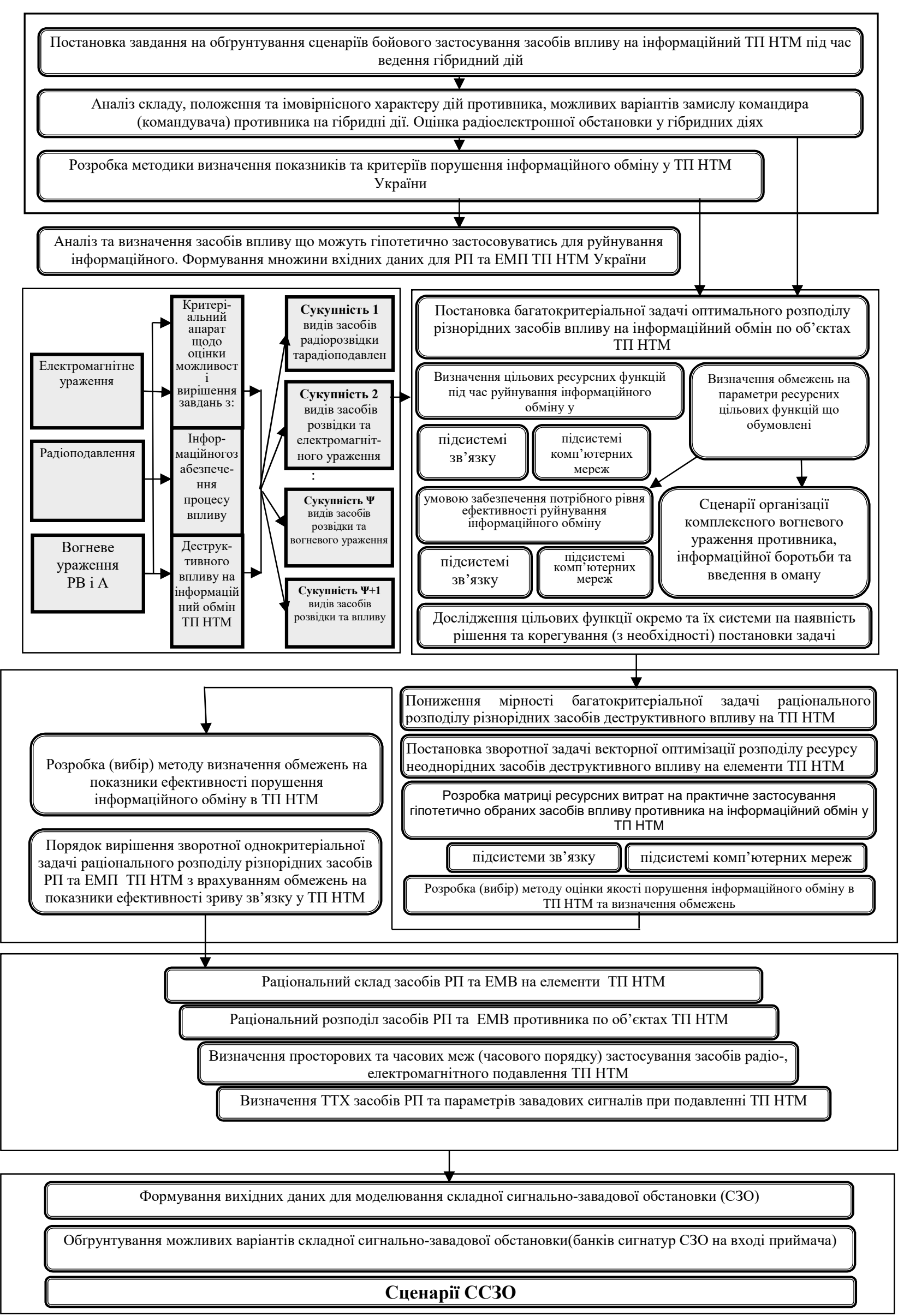

Рис. 1. Структура методики визначення сценаріїв РП, ЕМП ТП НТМ та складної сигнально-завадової обстановки 
Тоді, критерій для оцінки ефективності зриву інформаційного обміну в ТП НТМ шляхом РП та ЕМП противником іiі елементів при виконанні часткового завдання $Z_{j}$ має вигляд

$$
\mathrm{Q}_{\mathrm{j}}^{\Pi} \geq \mathrm{Q}_{\mathrm{j}}^{\mathrm{Kp}},
$$

де $\mathrm{Q}_{\mathrm{j}}^{\mathrm{Kp}}$ - критична кількість подавлених каналів транспортної мережі НTM, за якої досягається потрібний рівень порушення інформаційного обміну у транспортній мережі НТМ [7]

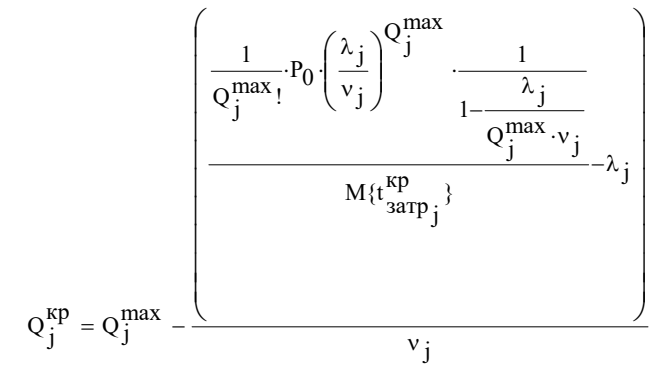

$$
\begin{aligned}
& P_{0}=\frac{1}{\sum_{i=1}^{\max }-1} \frac{1}{i !} \cdot\left(\frac{\lambda_{j}}{v_{j}}\right)^{i}+\frac{1}{Q_{j}^{\max } !} \cdot\left(\frac{\lambda_{j}}{v_{j}}\right)^{Q_{j}^{\max }} \cdot \frac{1}{1-\frac{\lambda_{j}}{Q_{j}^{\max } \cdot v_{j}}}
\end{aligned}
$$

де $\mathrm{Q}_{\mathrm{j}}^{\max }, \lambda_{\mathrm{j}}, v_{\mathrm{j}}$ - кількість каналів транспортної мережі НТМ, що розгорнуті, інтенсивність потоку повідомлень та середній час тривалості повідомлення у каналах транспортної мережі НТМ під час вирішення противником $\mathrm{j}$-го завдання;

$\mathrm{M}\left\{\mathrm{t}_{\text {saтp }_{\mathrm{j}}}^{\mathrm{kp}}\right\} \quad-$ математичне сподівання часу затримки передачі повідомлення в каналі транспортної мережі НТМ під час вирішення $\mathrm{j}$-го завдання.

Для вирішення завдань $Z_{1}, Z_{2}, \ldots, Z_{m}$ в процесі ведення гібридних дій (терористичної діяльності) противник має сформувати оптимальний набір $\mathrm{S}_{\mathrm{oпт}}=\left\|\mathrm{Q}_{\mathrm{jzk}}^{\Pi}\right\| \quad$ каналів об’єктів транспортної мережі НTM z -го типу, що подавляються відповідними засобами РП та ЕМП $\mathrm{k}$-го типу під час вирішення $\mathrm{j}$-го завдання, який забезпечуе мінімізацію економічних витрат реалізації способу бойового застосування засобів РП та ЕМП транспортної мережі НТМ під час ведення гібридних дій (терористичної діяльності). При цьому необхідне одночасне виконання вимог до ефективності процесу РП та ЕМП (наприклад, оптимізація за критерієм «вартість - ефективність подавлення»). Критерій «вартість - ефективність подавлення» не є єдиним можливим підходом та обраний для прикладу, як найбільш простий для розуміння порядку застосування методики, рис.1. На практиці необхідно визначити декілька можливих сценарії РП та ЕМП на основі застосування різних цільових функцій. Зокрема, доцільно застосовувати критерії «складність виконання бойового завдання - ефективність подавлення», або «вартість - складність виконання бойового завдання - ефективність подавлення».

Можливо поставити та вирішити задачу оптимального розподілу як багатокритеріальну та при визначенні сценаріїв обирати рівно ефективні варіанти призначення засобів РП та ЕМП з області Парето. Для цього в методиці, рис.1, додатково необхідно розробити:

схему компромісів особи що приймає рішення (ОПР) під час вирішення багатокритеріальної задачі;

метод визначення не гірших варіантів розподілу та відповідної номенклатури складу засобів РП та ЕМВ (визначення області Парето);

матрицю ресурсних витрат на практичне застосування гіпотетично обраних засобів впливу противника на інформаційний обмін у транспортній мережі НТМ тощо.

Однак формалізація постановки задачі багатокритеріальної оптимізації із застосуванням цільових функцій «вартість подавлення складність виконання бойового завдання ефективність подавлення» виходить за рамки роботи та буде вирішена авторами в окремій публікації.

$\mathrm{He}$ гублячи загальної мети, в процесі подальшого викладу порядку практичного застосування методики, рис.1, етап 3, в якості прикладу будемо розглядати однокритеріальну задачу за критерієм «вартість подавлення» при переведенні показника «ефективності подавлення» в режим обмежень. На разі врахуємо, що перехід від багатьох цільових функцій до однокритеріального варіанту можливий шляхом застосування методу переведення деяких з них у режим обмежень. Наприклад, ефективність зриву інформаційного обміну у ТП НТМ доцільно розглядати як обмеження мінімізуючи цільову функцію вартості.

Математична постановка задачі оптимального розподілу неоднорідних засобів РП та ЕМП противника за елементами транспортної мережі НТМ в гібридних діях (терористичній діяльності) має вигляд

$$
\mathrm{S}_{\text {опт }}\left(\mathrm{Q}_{\mathrm{jzk}}^{\Pi}\right)=\min \left\{\sum_{\mathrm{j}=1}^{\mathrm{m}} \sum_{\mathrm{z}=1}^{\mathrm{n}_{\mathrm{j}}} \sum_{\mathrm{k}=1}^{v} \mathrm{C}_{\mathrm{jzk}} \cdot \mathrm{Q}_{\mathrm{jzk}}^{\Pi}\right\}
$$

у разі обмежень на параметри цільової функції (4)

$$
\begin{aligned}
\sum_{\mathrm{z}=1 \mathrm{k}=1}^{\mathrm{n}_{\mathrm{j}}} \sum_{\mathrm{jz}}^{v} \mathrm{~A}_{\mathrm{j}} \cdot \mathrm{Q}_{\mathrm{jzk}}^{\mathrm{\Pi}} \geq \mathrm{Q}_{\mathrm{j}}^{\mathrm{Kp}}, \mathrm{j}=1,2, \ldots, \mathrm{m}, \mathrm{z}=1,2, \ldots, \mathrm{n}_{\mathrm{j}}(5) \\
\mathrm{Q}_{\mathrm{jzk}}^{\mathrm{\Pi}}=1,2, \ldots, \mathrm{Q}_{\mathrm{jzk}} \\
\mathrm{C}_{\mathrm{jzk}} \geq 0, \mathrm{k}=1,2, \ldots v .
\end{aligned}
$$

де $\mathrm{A}_{\mathrm{jz}}$ - кількість радіоканалів, організованих 
однією радіолінією об’єкта z -го типу j-ї ланки управління.

Об'єкти РП та ЕМП транспортної мережі НТМ складаються 3 сукупності приймальних або передаючих (при здійснення противником ЕМП) засобів СпЗ, Рр3 та УКХ радіозв’язку.

Кожний із засобів охарактеризований ймовірністю $\mathrm{P}_{\mathrm{yp}}$ jzk каналів, (перехід від ліній зв'язку до окремого каналу обумовлений врахування багатоканальності ліній зв'язку) яка $є$ функцією характеристик радіовпливу на Об РП z -го типу відповідним k-м типом засобів РП [4-6]. Визначена кількість каналів $Q_{j z}$ та максимальна кількість каналів $\mathrm{Q}^{\max }$ jz засобів ТП НТМ, що розгорнуті на окремому та сукупності однотипних об'єктів z -го типу під час вирішення j-го завдання відповідно.

За результатами воєнно-економічного аналізу необхідно сформувати матрицю $\left\|\mathrm{C}_{\text {jzk }}\right\|$ економічних витрат РП та ЕМП на кожен канал транспортної мережі НТМ об'єкту z-го типу засобами РП k -го типу, таблиця 1.

Елементи матриці формуються із врахуванням захисних властивостей кожного типу Об РП, ЕМП та живучості засобів РП кожного типу, де $\mathrm{C}_{\mathrm{jzk}}=\frac{\mathrm{C}_{\mathrm{k}} \cdot \mathrm{M}_{\mathrm{jzk}}}{\mathrm{Q}_{\mathrm{jz}} \cdot \mathrm{G}_{\mathrm{jzk}}^{\text {म }}} ; \mathrm{C}_{\mathrm{k}} \cdot \mathrm{M}_{\mathrm{jzk}}\left(\mathrm{P}_{\mathrm{yp}} \mathrm{jzk}\right)-$ відповідно вартість застосування засобу РП та ЕМП k-го типу противника та їх кількість, яка необхідна для ураження (подавлення) Об РП z -го типу засобом РП k-го типу під час вирішення ј-го завдання; $\mathrm{G}_{\mathrm{jzk}}^{\text {д }}$ - коефіцієнт, що характеризує ступінь виконання завдання 3 доставки засобів РП, ЕМП $\mathrm{k}$-го типу до Об РП $z$-го типу під час вирішення j-го завдання $\left(0<\mathrm{G}_{\mathrm{jzk}}^{\text {д }} \leq 1\right)$. Ця процедура труднощів не викликає.

Аналіз (1-7) дозволяє зробити висновок, що на третьому етапі методики задача розподілу засобів РП и ЕМП по Об при розробці можливих сценаріїв РП та ЕМП противником транспортної мережі НТМ за критерієм «вартість подавлення ефективність подавлення» може бути зведена до вирішення багатоіндексної двоякої цілочисельної зворотної задачі лінійного програмування.

Метод мінімізації (4) суттєво визначається іï мірністю та характером сукупності обмежень типу (5-7). Підходи до вирішення зворотних двояких задач досліджені в $[7,8]$. Однак результати отримані або в умовах розподілу однорідного ресурсу, або невисокої індексності (не більш 2) цільової функції та їх використання для отримання однозначного рішення задачі (4-7) утруднено.
Іншим підходом до зняття виникаючих протиріч на третьому етапі методики $\epsilon$ багаторівневий процес вирішення (4-7) 3 пониженням мірності цільової функції (4) задачі за рахунок перетворення матриці економічних витрат $\left\|\mathrm{C}_{\mathrm{jzk}}\right\|$. В результаті чого, формується матриця економічних витрат, яка приводиться до матриці-строки $\mathrm{C}_{\mathrm{z}}$, таб.2, шляхом згортання за правилом, згідно з яким, з елементів кожного z -го стовпця матриці $\left\|\mathrm{C}_{\mathrm{jzk}}\right\|$ обирається мінімальний та його значення присвоюється відповідному елементу матриці-строки $\mathrm{C}_{\mathrm{z}}^{\mathrm{k}}$ зі збереженням індексу $\mathrm{z}$, де верхній індекс $\mathrm{k} \epsilon$ типом засобу РЕП, що чисельно дорівнює номеру строки в якій знаходився мінімальний для $\mathrm{z}$-го стовпця елемент матриці $\left\|\mathrm{C}_{\mathrm{jzk}}\right\|$.

В результаті запропонованого підходу, задача (4-7) спрощується до вигляду

$$
\mathrm{S}_{\text {опт }}\left(\mathrm{Q}_{\mathrm{Z}}^{\Pi}\right)=\min \left\{\sum_{\mathrm{z}=1}^{\mathrm{n}_{\mathrm{j}}} \mathrm{C}_{\mathrm{z}}^{\mathrm{k}} \cdot \mathrm{Q}_{\mathrm{Z}}^{\Pi}\right\}
$$

у разі обмежень:

$$
\begin{gathered}
\sum_{\mathrm{z}=1}^{\mathrm{n}_{\mathrm{j}}} \mathrm{Q}_{\mathrm{z}} \geq \mathrm{Q}_{\mathrm{j}}^{\mathrm{kp}}, \mathrm{j}=1,2, \ldots, \mathrm{m}, \mathrm{z}=1,2, \ldots, \mathrm{n}_{\mathrm{j}} \\
\mathrm{Q}_{\mathrm{jz}}=1,2, \ldots, \mathrm{Q}_{\mathrm{jz}}^{\max } \\
\mathrm{C}_{\mathrm{jz}}^{\mathrm{k}} \geq 0, \mathrm{k}=1,2, \ldots, v .
\end{gathered}
$$

Фізична трактовка (8)...(11) може бути наступною [5]. До кожного завдання $Z_{1}, Z_{2}, \ldots, Z_{m}, j=1,2, \ldots, m, \quad$ необхідно надати (створити під часгібридних дій) різнорідний ресурс каналів транспортної мережі НТМ що подавлені або уражені $\mathrm{n}_{\mathrm{j}}$ типів, у разі обмежень зверху на їх сукупну кількість $Q_{j z}^{\max }$ за типами об'єктів та знизу на сукупну кількість подавлених каналів в межах кожного завдання, що вирішується (9).

Для вирішення задачі виду (8-11), виникає необхідність пошуку методу розв'язання. Проведений аналіз меж застосування відомого методичного апарату $[5,6,8,9]$ дозволили побудувати алгоритм оптимізації (8-11) на основі методу нормованих функцій, який детально розроблений авторами в [6].

В якості прикладу застосуємо підхід (1-11), рис.1,2 та результати табл.1, 2 для виконання етапу III методики при розробці сценаріїв РП та ЕМП транспортної мережі НТМ під час зриву державного управління в гібридних діях (терористичній діяльності) на глибину до 300 км. 
Таблиця 1

Приклад результатів формування матриці $\left\|\mathrm{C}_{\mathrm{jzk}}\right\|$ економічних витрат РП та ЕМП на кожен канал ТП НТМ об'єкту $z$-го типу засобами подавлення k -го типу

\begin{tabular}{|c|c|c|c|c|c|c|c|c|c|c|}
\hline \multirow{3}{*}{\multicolumn{3}{|c|}{$\begin{array}{c} \\
\text { Об'єкти } \\
\text { РП та ЕМП ТП НТМ }\end{array}$}} & \multicolumn{8}{|c|}{$\begin{array}{c}\text { Номер завдання (в залежності від просторових меж виконання } \\
\text { завдань противником) з подавлення елементів ТП НТМ, } j \text { та } \\
\text { номер типового } \\
\text { Об РП та ЕМП (від } 1 \text { до 8) } \\
\end{array}$} \\
\hline & & & \multicolumn{3}{|c|}{$j=1$} & \multicolumn{4}{|c|}{$j=2$} & \multirow{2}{*}{ 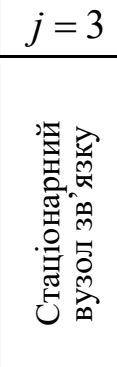 } \\
\hline & & & 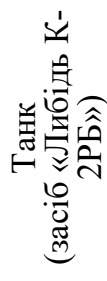 & 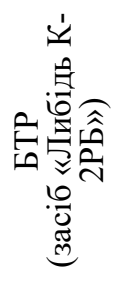 & 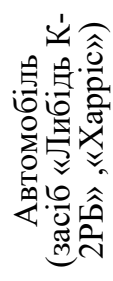 & 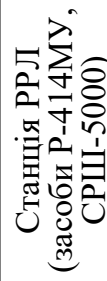 & 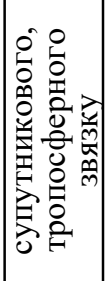 & 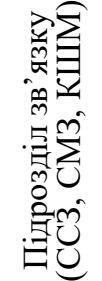 & 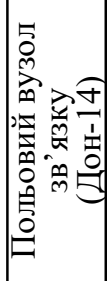 & \\
\hline $\begin{array}{c}\text { Тип засобу РП та } \\
\text { ЕМП }\end{array}$ & $\begin{array}{l}\text { Тип } \\
\text { засобу } \\
\text { РП та } \\
\text { ЕМП }\end{array}$ & $\begin{array}{c}\text { Спосіб } \\
\text { доставки }\end{array}$ & 1 & 2 & 3 & 4 & 5 & 6 & 7 & 8 \\
\hline \multirow{4}{*}{ ЕМП } & 1 & БПЛА & 300 & 300 & 300 & 700 & 700 & 2000 & 10000 & 100000 \\
\hline & 2 & АБП & 3230 & 3230 & 3230 & - & - & - & - & - \\
\hline & 3 & $\mathrm{AБ}$ & 30000 & 30000 & 30000 & 30000 & 50000 & 50000 & 50000 & 100000 \\
\hline & 4 & ДРГ & 1100 & 1200 & 1200 & 1500 & 2200 & 2500 & 3000 & 10000 \\
\hline РП - БПЛА - ПЗ & 5 & БПЛА & 200 & 200 & 300 & 500 & 1000 & 1000 & 5000 & 5000 \\
\hline $\begin{array}{l}\text { РП - } 377 \text { ЛА } \\
\text { Лорандит» } \\
\text { УКХ: 30-300 МГц } \\
\end{array}$ & 6 & НВП & 771 & 771 & 771 & 771 & - & - & - & - \\
\hline $\begin{array}{l}\text { РП - «Репеллент-1» } \\
(200-6000 \text { МГц) }\end{array}$ & 7 & НВП & 1748 & 1748 & 1748 & 1748 & - & - & - & - \\
\hline $\begin{array}{l}\text { PП - Р-330Ж } \\
\text { «Житель» } \\
\text { GSM-900/1800 } \\
\end{array}$ & 8 & НВП & 1748 & 1748 & 1748 & 1748 & - & - & - & - \\
\hline $\begin{array}{l}\text { РП - «Борисоглебск-2» } \\
\text { КХ (1,5-30 МГц); } \\
\text { УКХ (30-100 МГц) }\end{array}$ & 9 & НВП & 3178 & 3178 & 3178 & 3178 & 3178 & - & - & - \\
\hline $\begin{array}{l}\text { РП - Р-934У } \\
\text { УКХ (30-300 МГц); } \\
\text { GSM-900/1800 }\end{array}$ & 10 & НВП & 1748 & 1748 & 1748 & - & - & - & - & - \\
\hline $\begin{array}{l}\text { РП - «ТОРН» } \\
\text { КХ (3-30МГц); } \\
\text { УКХ (до 3000 МГц); }\end{array}$ & 11 & НВП & 1748 & 1748 & 1748 & - & - & - & - & - \\
\hline $\begin{array}{l}\text { РП - РБ-109А } \\
\text { «Былина» } \\
\text { Супутниковий, } \\
\text { мобільний, РРЛ, } \\
\text { транкінговий зв'язок }\end{array}$ & 12 & НВП & 8770 & 8770 & 8770 & 8770 & 8770 & 8770 & 8770 & 8770 \\
\hline РП - ЗПЗ - ДРГ & 13 & ДРГ & 1500 & 1500 & 1500 & 2000 & 2000 & 3000 & 4000 & 5000 \\
\hline
\end{tabular}

Примітка. Умовні позначення: БПЛА ПЗ - безпілотний літальний апарат постановник завад; АБП - артилерійський боєприпас; АБ - авіаційна бомба; НВП - направлений випромінюючий пристрій; ДРГ - диверсійна розвідувальна група, ЗПЗ - передавач завад,постановщик завад, що розміщується недалеко від об'єкту впливу.

Нехай, при цьому необхідно вирішити три часткових завдання - зірвати інформаційний обмін у мережах державного управління відповідно на глибину до 20 км ( $\mathrm{j}=1)$, від 20 до 100 км ( $\mathrm{j}=2)$ та від 100 до 300 км $(\mathrm{j}=3)$, табл.3.
За результатами ведення радіоелектронної, космічної, агентурної розвідки противником визначені у складі транспортної мережі НТМ типи об’єктів РП та ЕМП ( $\mathrm{z}=8$ ), табл.1, 2. В таблиці 3 наведена загальна кількість ліній зв'язку розгорнутих на всіх об'єктах кожного z -го типу. 
Приклад результатів приведення матриці економічних витрат $\left\|\mathrm{C}_{\mathrm{jzk}}\right\|$ до матриці-строки $\mathrm{C}_{\mathrm{z}}$

\begin{tabular}{|c|c|c|c|c|c|c|c|c|}
\hline & \multicolumn{7}{|c|}{ Номер типового Об РП та ЕМП (див. табл.1) } \\
\hline$z$ & 1 & 2 & 3 & 4 & 5 & 6 & 7 & 8 \\
\hline$k$ & 3 & 3 & 3 & 6 & 6 & 4 & 4 & 2 \\
\hline$C_{z}^{k}$ & 200 & 200 & 300 & 500 & 500 & 500 & 1000 & 1000 \\
\hline
\end{tabular}

Таблиця 3

Формування матриці загальної кількості ліній зв'язку розгорнутих на всіх об'єктах кожного $Z$-го типу.

\begin{tabular}{|c|c|c|c|c|c|c|c|c|}
\hline $\begin{array}{c}\text { Номер } \\
\text { часткового } \\
\text { завдання }\end{array}$ & 1 & 2 & 3 & 4 & 5 & 6 & 7 & 8 \\
\hline 1 & 10 & 10 & 20 & - & - & - & - & - \\
\hline 2 & - & - & - & 20 & 10 & 10 & 15 & - \\
\hline 3 & - & - & - & - & - & - & - & 35 \\
\hline
\end{tabular}

Таблиця 4

Необхідна кількість каналів ТП НTM $\left(\mathrm{Q}_{\mathrm{j}}^{\mathrm{\kappa p}}\right.$ ), що подавлені (ураженні) при якій забезпечується зрив інформаційного обміну у ТП НТМ при вирішенні кожного часткового завдання

\begin{tabular}{|c|c|}
\hline $\begin{array}{c}\text { Номер завдання (в залежності від просторових меж } \\
\text { виконання завдань противником) з подавлення } \\
\text { елементів ТП НТМ, } j\end{array}$ & $Q_{j}^{\text {кр }}$ \\
\hline $\mathrm{J}=1$ & $Q_{1}^{\mathrm{\kappa p}}=12$ \\
\hline $\mathrm{J}=2$ & $Q_{j}^{\mathrm{\kappa p}}=9$ \\
\hline $\mathrm{J}=3$ & $Q_{j}^{\text {кр }}=19$ \\
\hline
\end{tabular}

Для РП та ЕМП противником гіпотетично може бути сформована сукупність із $\mathrm{k}=13$ типів засобів РП та ЕМП, табл.1.

В матриці-стовпці Q наведена, визначена на основі методики (2-3), необхідна кількість каналів транспортної мережі НTM $\left(\mathrm{Q}_{\mathrm{j}}^{\mathrm{\kappa p}}\right)$, що подавлені (ураженні), при якій забезпечується зрив інформаційного обміну у транспортній мережі НТМ при вирішенні кожного часткового завдання відповідно. Результати оптимального розподілу кількості каналів транспортної мержеі НТМ об'єктів z типів, k типів засобів РП та ЕМП по типовим Об для зриву інформаційного обміну у транспортній мережі НТМ у проміжок часу 4 години наведені в табл. $5 \mathrm{~W}\left(\mathrm{Q}_{\mathrm{z}}^{\Pi}\right)$. При цьому, мінімальне значення цільової функції (8) за обмежень (9-11) Sopt дорівнює $1,17 * 10^{5}$, дол. США.

Таблиця 5

Результати оптимального розподілу кількості каналів ТП НТМ об’єктів $z$ типів, k типів засобів РП та ЕМП по типовим Об для зриву інформаційного обміну у ТП НТМ у проміжок часу 4 години

Номер завдання (в залежності від просторових меж виконання завдань противником) 3 подавлення елементів ТП НТМ, ${ }^{j}$ та номер типового Об РП та ЕМП (від 1 до 8)

\begin{tabular}{|c|c|c|c|c|c|c|c|}
\hline \multicolumn{3}{|c|}{$j=1$} & \multicolumn{4}{|c|}{$j=2$} & $j=3$ \\
\hline 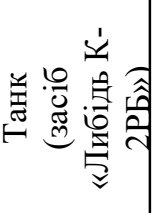 & 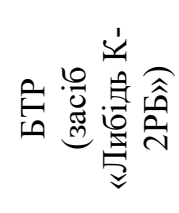 & 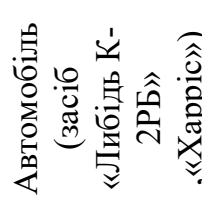 & 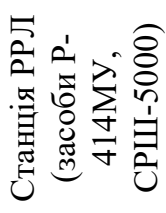 & 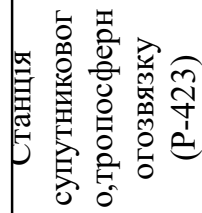 & 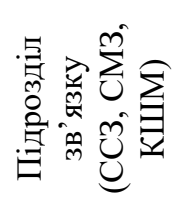 & 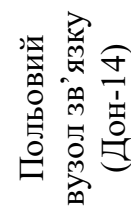 & 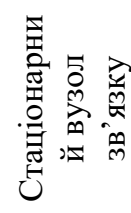 \\
\hline 2 & 1 & 9 & 2 & 3 & 4 & 3 & 19 \\
\hline
\end{tabular}

Тип засобу РП та ЕМП що може бути застосований для завдання з порушення інформаційного обміну ТП НТМ (див. табл.1) та кількість (наведена у дужках)

\begin{tabular}{|c|c|c|c|c|c|c|c|}
$5(2)$ & $5(2) ; 13(1)$ & $5(2) ; 3(2)$ & $5(2) ; 13(2)$ & $12(1) ; 5(2)$ & $5(3) ; 12(1)$ & $5(4) ; 12(2) ;$ & $\begin{array}{c}5(5) ; 12(2) ; \\
13(2)\end{array}$ \\
\hline
\end{tabular}


Результати таблиця 5 дозоляють визначити сценарій РП та ЕМП транспортної мережі НТМ за цільовою функцією пониженої мірності (8) при виконанні противником завдань у відповідних територіальних межах за умови гарантованого зриву інформаційного обміну. При цьому економічні витрати противника - мінімальні.

Для визначення сценарію необхідно щоб ураження (подавлення) відповідних об'єктів РП було узгоджено за просторовими та часовими вимогами їх виконання.

Іншій варіант сценарію може бути отриманий варіаціями множини обмежень, оперативнотактичних умов або зміною сутності та виду цільової функції.

На п'ятому етапі методики за результатами розробки сценарію РП та ЕМП транспортної мережі НТМ формуються данні щодо видів завадових сигналів противника, їх кількості, параметрів та порядку випромінювання, дій станцій зв’язку тощо. Це дає змогу статистично описати можливі варіанти СС3О за якої гіпотетично буде здійснюватися застосування підрозділів Держспецзв'язку за призначенням в умовах реалізації противником визначених сценаріїв РП та ЕМП транспортної мережі НТМ. Для цього шляхом математичного та імітаційного моделювання формуються вибірки можливих значень амплітуди суперпозиції спектрів корисних сигналів, адитивних шумів та завад різних типів (структурних, подібних та гармонічних вузькосмугових завад), що можуть випромінюватись обраними за результатами етапу III засобами РП противника. Моделюються реальні дистанції зв'язку, тактико-технічні характеристики засобів РП противника та своїх засобів зв'язку, реальні види завадових сигналів.

За результатами моделювання формуються вибірки розрахованих амплітуд суміші корисного сигналу та завад на фоні власних шумів приймача для різних сценаріїв РП та ЕМП транспортної мережі НТМ противником. Далі будуються гістограми вибіркового розподілу сумарної амплітуди спектру на вході приймача та вирішуються задачі статистичної перевірки гіпотез, що є підставою для вибору типу закону розподілу амплітуди спектру суміші «сигнал гаусів шум - завада». Таким чином, створюється апріорний словник сигнатур або паттернів станів випадкових процесів на вході приймача.

Задача 3 перевірки гіпотези про закон розподілу вибірки випадкової величини може бути вирішена із застосуванням відомих критеріїв, наприклад Пірсона (критерій $\chi^{2}$ ) і Колмогорова [10].

У разі застосування критерію $\chi^{2}$ дискретизується функція, що описує зміни амплітуди спектру суміші сигналу, завади та шуму на вході приймача. Далі формується вибірка обсягу $\mathrm{n}$, яка розбивається на $\mathrm{k}$ інтервалів (від 8 до 20). Кількість елементів вибірки, що потрапили в $\mathrm{i}$-інтервал, позначимо через $\mathrm{n}_{\mathrm{j}}$. Побудована за цими даними гістограма вибіркового розподілу амплітуди сигналу служить підставою для вибору типу закону розподілу. Параметри цього розподілу можуть бути знайдені або 3 теоретичних міркувань, або знаходженням їх оцінок за вибіркою. На підставі прийнятого закону розподілу обчислюються ймовірності $\mathrm{p}_{\mathrm{i}}$ попадання випадкової величини в $\mathrm{i}$-інтервал. Величина, що характеризує відхилення вибіркового розподілу від передбачуваного, визначається формулою [10]:

$$
\chi^{2}=\sum_{\mathrm{i}=1}^{\mathrm{k}} \frac{\left(\mathrm{n}_{\mathrm{i}}-\mathrm{np}_{\mathrm{i}}\right)^{2}}{n \mathrm{p}_{\mathrm{i}}}
$$

де $\mathrm{k}$ - кількість інтервалів; $\mathrm{n}$ - обсяг вибірки.

Сума (12) має наближено $\chi^{2}$ - розподілення $3 \mathrm{f}=(\mathrm{k}-1-\mathrm{c})$ ступенями вільності, де c -кількість параметрів гіпотетичного закону розподілу, що визначаються за вибіркою. Для нормального розподілу $\mathrm{c}=2$, якщо $\mathrm{i} \overline{\mathrm{x}}$, i $\mathrm{s}$ визначаються за даною вибіркою.

Гіпотеза про прийнятий тип закону розподілу приймається на обраному рівні значущості $\alpha$, якщо $\chi^{2} \leq \chi_{1-\alpha}^{2}$, де $\chi_{1-\alpha}^{2}$ квантиль розподілу Пірсона для даного $\alpha$ i кількості ступенів вільності f. В іншому випадку робиться висновок про те, що гіпотеза не узгоджується з вибірковим розподілом.

При використанні критерію $\chi^{2}$ бажано, щоб обсяг вибірки був достатньо великим: $\mathrm{n} \geq 50 \div 150$, а кількість елементів $\mathrm{n}_{\mathrm{j}} \geq 5 \div 8$.

При підрахунку теоретичних ймовірностей $\mathrm{p}_{\mathrm{i}}$ вважається, що крайній лівий інтервал простягається до - $\infty$; крайній правий до $+\infty$.

Для застосування критерію згоди Колмогорова необхідно визначити найбільше абсолютне відхилення вибіркової функції розподілу $\mathrm{F}_{\mathrm{n}}(\mathrm{x})$ від генеральної $\mathrm{F}(\mathrm{x})$ [10]:

$$
\mathrm{D}=\max \left|\mathrm{F}_{\mathrm{n}}(\mathrm{x})-\mathrm{F}(\mathrm{x})\right|
$$

потім обчислити величину $\lambda=\mathrm{D} \sqrt{\mathrm{n}}, \lambda_{1-\alpha}-$ квантиль розподілу Колмогорова.

Якщо $\lambda>\lambda_{1-\alpha}$, то гіпотеза про збіг теоретичного закону розподілу $\mathrm{F}(\mathrm{x})$ з вибірковим $\mathrm{F}_{\mathrm{n}}(\mathrm{x})$ не відхиляється. При $\lambda>\lambda_{1-\alpha}$ гіпотеза відхиляється (або вважається сумнівною). Рівень значущості при застосуванні критерію 
Колмогорова обирають зазвичай в діапазоні $(0,2 \ldots 0,3)$.

У разі вибірок невеликого обсягу $(\mathrm{n}<50)$ для перевірки гіпотези про закон розподілу можна використовувати прості критерії, засновані на порівнянні генеральних параметрів розподілу і їх оцінок, отриманих за вибіркою. В якості оцінок параметрів найзручніше обрати моменти.

Для опису різних моделей завад з можливістю оцінки їх майбутньої поведінки можливо застосувати ймовірнісні конструкції та підхід (9-12). Негаусівські завади можливо описати кінцевою послідовністю кумулянтів. Однак на практиці для поточного моменту $\mathrm{t}$ доцільно мати представлення про поведінку завади в момент $\mathrm{t}+\mathrm{\kappa}, \mathrm{k} \geq 1$. Для вирішення цього завдання потрібно знати мати умовну сумісну щільність ймовірності значень амплітуди суміші сигналу, шуму та завад $(\mathrm{t}+\mathrm{\kappa}), \quad \mathrm{k} \geq 1$ при заданому наборі попередніх значень амплітуди. Однак у більшості практичних випадків реалізація цієї ідеї потребує великої кількості обчислень. В такий ситуації, розвиваючи підхід [10] у галузь моделювання завадової обстановки можливо формалізувати заваду співвідношенням [11]

$$
\mathrm{v}(\mathrm{t})=\sum_{\mathrm{k}=0}^{\infty} \mathrm{h}(\mathrm{k}) \cdot \mathrm{e}(\mathrm{t}-\mathrm{k}),
$$

де $\mathrm{e}(\mathrm{t})$ - послідовність взаємно незалежних однаково розподілених випадкових величин 3 деякою функцією щільності ймовірності. Такий підхід дозволяє в подальшому здійснювати визначення сценаріїв та формування статистичних гіпотез про майбутню поведінку завади. Новизна

\section{Лimepamypa}

1. Шолохов С. М., Тищук С.О., Завацький О. Б., Лучук Е. Електромагнітна зброя: сутність, принципи застосування та перспективи використання в операціях (бойових діях). Вісник воєнної розвідки. 2005. № 1(10). C. 39-43.2. VanNottenPh. Scenario development: a typology of approaches. Think Scenario. Rethink Education. 2006. P. 69-84.3. Wack P. Scenarios: Shooting the Rapids. Harvard Business Review. 1985. № 5. P. 7229.4. VanNottenPh. Writing on the wall: scenario development in times of discontinuity. Boca Raton : MU, 2005. 209 р. 5. Шолохов С. М., Завацький О. Б., Лучук Е. В., Онисько А. І., Тіхонов Г. М. Методика обгрунтування оптимальних способів радіоелектронного подавлення новітніх АCУ противника частинами, що оснащені зброєю РЕБ нового покоління. Труди академіі. 2006. № 66. С. 112-119. 6. Шолохов С. М., Гордієнко Ю. В. Постановка зворотної задачі раціонального розподілу ресурсу неоднорідних засобів радіоелектронної боротьби противника по елементах транспортної платформи національної такого підходу полягає у можливості апроксимації складних по формі завад шляхом визначення (підбору) різних функцій щільності ймовірності для послідовності $\mathrm{e}(\mathrm{t})$ може моделювати (імітувати по формі) завади практично любого характеру складності. Цей практичний висновок відіграє важливу роль у створенні при подальших дослідженнях словника сигнатур ознак станів випадкових процесів на вході приймача у складній С3О, дозволяє проводити дослідження 3 розпізнавання стану ССЗО за сформованими у процесі навчання патернами.

\section{Висновки й перспективи подальших досліджень}

Запропонований підхід дозволяє вирішувати завдання з визначення сценаріїв:

РП та ЕМП транспортної мережі НТМ на основі розподілу неоднорідних засобів РП та ЕМП противника за елементами транспортної мережі НТМ у гібридних діях (терористичній діяльності);

ССЗО що може скластися у інформаційному конфлікті засобів спеціального зв'язку та РЕБ противника.

В рамках подальших досліджень доцільно створити методику розробки апріорного словника сигнатур та паттернів станів випадкових процесів на вході приймального засобу спецзв'язку. Це надасть можливості в подальшому синтезувати автоматизовані непараметричні статистичні та нейромережеві алгоритми розпізнавання станів ССЗО. Розроблені алгоритмі розпізнавання станів ССЗО дозволяють в подальшому розробити адаптивні до стану ССЗО алгоритмів завадозахисту.

телекомунікаційної мережі для визначенні сценаріїв іiі радіоелектронного подавлення. Спеціальні телекомунікаційні системи та захист інформації. 2020. № 1(7). С. 34-40. 7. Шолохов С. М., Гордієнко Ю. В. Оцінка ефективності радіоелектронного та програмнокомп'ютерного подавлення телекомунікаційних систем урядового зв'язку при обгрунтуванні перспективних способів їх радіоелектронного захисту в умовах ведення гібридної війни. Спеціальні телекомунікаційні системи ma захист інформації. 2019. № 2(6). С. 59-65. 8. Берзин Е. А.Оптимальное распределение ресурсов и элементы синтеза систем. / под ред. Е. В.Золотова. Москва : Советское радио,1974. 303 с. 9. Гурин Л. С., Дымарский Я. С., Меркулов А. Д.Задачи и методы оптимального распределения ресурсов. Москва: Советское радио. 1968.463 с. 10. Гмурман В. Е. Теория вероятностей и математическая статистика. Москва : Высшая школа, 1972. 368 с. 11.Льюнг Л. Идентификация систем. Теория для пользователя / пер. с англ. / под.ред. Я. З. Цыпкина. М. :Наука, 1991. 432 с. 


\title{
МЕТОДИКА РАЗРАБОТКИ СЦЕНАРИЕВ РАДИОЭЛЕКТРОННОГО И ЭЛЕКТРОМАГНИТНОГО ПОДАВЛЕНИЯ НАЦИОНАЛЬНОЙ ТЕЛЕКОММУНИКАЦИОННОЙ СЕТИ В УСЛОВИЯХ ОСОБОГО ПЕРИОДА
}

\author{
Тихонов Григорий Митрофанович (кандидат военных наук, с.н.с.) ${ }^{1}$ \\ Шолохов Сергей Николаевич (кандидат технических наук, доцент) ${ }^{2}$ \\ Гордиенко Юрий Викторович ${ }^{2}$
}

\begin{abstract}
${ }^{1}$ Национальный университет обороны Украины имени Ивана Черняховского, Киев, Украина ${ }^{2}$ Национальный технический университет Украины «Киевский политехнический институт имени Игоря Сикорского», Киев, Украина
\end{abstract}

Помехозащищценность системы связи является актуальным и важным направлением исследования, методология оценки воздействия на него средств радио (РП) и электромагнитного подавления (ЭМП), на сегодняшний день, достаточно развита и известна. Национальная телекоммуникационная сеть (НТС), как совокупность систем и сетей связи, в условиях ведения гибридной войны против Украины нуждается в совершенствовании способов ее зашить от деструктивного влияния противника, который имеет на вооружении новейтие средства РП и ЭМП. Незащищенная НТС не сможет выполнить основную свою функиию, а именно обращение (передача, прием, создание, обработка, хранение) и защита нацииональных информационных ресурсов, обеспечение защчищенных электронных коммуникаций, предоставление спектра современных защчищенных информационно-коммуникационных (мультисервисных) услуг в интересах осуществления управления государством в мирное время, в условиях чрезвычайного положения и в особый период, и которая является сетью (системой) двойного назначения с использованием части ее ресурса для предоставления услуг, в частности с киберзащиты, другим потребителям. Качественная разработка способов и методов обеспечения помехоустойчивости элементов НТС невозможна без прогнозирования возможных сиенариев действий противника и помеховой обстановки, которая может сложиться.

Предложено применение сиенарного подхода при разработке адаптивных алгоритмов помехозащищенности средств специальной связи от активного радио и электромагнитного подавления противника в гибридных действиях и террористической деятельности.

Разработана методика обоснования сиенариев РП и ЭМП транспортной платформы (ТП) НТС и определения сценариев сложной сигнально-помеховой обстановки. Данные сценарии необходимые для дальнейшего синтеза адаптивных алгоритмов помехозащчщзенности средств ТП НТС.

Методика позволяет обосновать состав и порядок применения средств РП и ЭМП противника во времени и по элементам ТП НТС в условиях ведения гибридных боевых действий против Украины.

Сделан вывод о необходимости синтеза алгоритмов помехозащищенности каналов связи адаптивных к разным сиенариям сигнально-помеховой обстановки, которая может сложиться.

Ключевые слова: электромагнитное подавление; радиоэлектронное подавление; сценарии радиоподавление; помехозащчищенность.

\section{METHODOLOGY OF DEVELOPING SCENARIOS OF RADIOELECTRONIC AND ELECTROMAGNETIC SUPPRESSION OF NATIONAL TELECOMMUNICATIONS NETWORK IN THE CONDITIONS OF THE SPECIAL PERIOD}

\author{
Tikhonov Grigorii (Candidate of Military Sciences, Senior Research Fellow) ${ }^{1}$ \\ Sholokhov Serhii (Candidate of Technical Sciences, Associate Professor) ${ }^{2}$ \\ HordiienkoYurii ${ }^{2}$
}

\begin{abstract}
${ }^{1}$ National Defence University of Ukraine named after Ivan Cherniakhovskyi, Kyiv, Ukraine
${ }^{2}$ National Technical University of Ukraine "Igor Sikorsky Kyiv Polytechnic Institute", Kiev, Ukraine
\end{abstract}

Annotation. Interference protection of the communication system is a relevant and important researching area, impact assessment methodology of radio (RS) and electromagnetic suppression (EMS) is rather developed and known for today. The National Telecommunication Network (NTN), as a set of communication systems and networks, in the context of a hybrid war against Ukraine requires protection improvement from the destructive influence of the enemy, which has the latest RP and EMF. Unsecured NTN will not be able to perform its main function, namely the circulation (transmission, reception, creation, processing and storage) and protection of national information resources, providing secure electronic communications, providing a range of modern 
secure information and communication (multiservice) services in the interests of government in peacetime, in a state of emergency and during a special period. In addition, NTN is a dual-purpose network (system) with partial usage of its resources to provide services, including cyber security, to other consumers. Qualitative development of methods and techniques to ensure interference protection of NTN elements is impossible without predicting possible scenarios of the enemy and the interference situation that may arise.

It is proposed to use scenarios approach during adaptive algorithm development of interference protection of special means of communication against active radio and electromagnetic suppression of the enemy in hybrid actions and terrorist activities.

The method of substantiation of scenarios of RS and EMS of the transport platform (TP) of NTM and determination of scenarios of complex signal-interference situation is developed. These scenarios are necessary for the further synthesis of adaptive interference protection algorithms of TP NTN.

The method allows substantiating the composition and usage of RS and EMS measures of enemy within the timeline and $b$ the elements of TP NTN terms of hybrid war against Ukraine.

It is concluded that it is necessary to synthesize the interference protection algorithms of communication channels, which will be adaptive to different scenarios of signaling, and interference situation that may occur.

Key words: electromagnetic suppression; electronic suppression; scenarios of radio suppression; emergency protection.

\section{References}

1. Sholokhov S. M., Tishchuk S. O., Zavatskiy O.B., Luchuk E. Electromagnetism of weapon: day, principle of storing that perspective of use in operations (combat actions). Newsletter of military development. 2005. No. 1 (10). S. 39-43. 2. Van NottenPh. Scenario development: a typology of approaches. Think Scenario. Rethink Education. 2006. P. 69-84. 3. Wack P. Scenarios: Shooting the Rapids. Harvard Business Review. 1985. No. 5. P. 72-29. 4. Van NottenPh. Writing on the wall: scenario development in times of discontinuity. Boca Raton: MU, 2005.209 p. 5. Sholokhov S. M., Zavatsky O. B., Luchuk E. V., Onisko A. I., Tikhonov G. M. Methods of determining the optimal methods of radio-electronic suppression of the enemy's new ACS with parts, which are equipped with the new generation REB. Trudy Academy. 2006. No. 66, pp. 112-119. 6. Sholokhov S. M., HordiienkoY. V. Statement of the zealous task of rational development of the resource of the disparate radio-electronic struggle of the enemy on the elements of the transport platforms of the national telecommunication measure for the purpose of suppressing the scenario. Special Telecommunications Systems and Information Security. 2020. No. 1 (7). S. 34-40. 7. Sholokhov S. M., Hordiienko Yu. V. Assessment of the efficiency of radioelectronic and software-computer suppression of telecommunication systems of radio communication in the case of promising new methods of radio-electronic control in the power supply system. Special Telecommunications Systems and Information Security. 2019. No. 2 (6). S. 5965. 8. Berzin E. A.Optimal distribution of resources and elements of systems synthesis. / ed. E. V. Zolotova. Moscow: Soviet Radio, 1974. 303 s. 9. Gurin L. S., Dymarskiy Y. S., Merkulov AD Problems and methods of optimal distribution of resources. Moscow: Soviet radio. 1968. 463 s. 10. Gmurman V. E. Probability theory and mathematical statistics. Moscow: Higher school, 1972. 368 p. 11.Ljung L. Systems identification. Theory for the user /trans. from English. / ed. Y.Z. Tsypkina. Moscow: Nauka, 1991.432. 